\title{
SALT STRESS AND AMBIENCE ON THE PRODUCTION OF WATERMELON SEEDLINGS ${ }^{1}$
}

\author{
FRANCISCO BARROSO DA SILVA JUNIOR ${ }^{2 *}$, GEOCLEBER GOMES DE SOUSA ${ }^{3}$, JOSÉ THOMAS MACHADO \\ DE SOUSA ${ }^{3}$, CARLA INGRYD NOJOSA LESSA ${ }^{3}$, FRED DENILSON BARBOSA DA SILVA ${ }^{3}$
}

\begin{abstract}
The objective of this study was to evaluate the production of watermelon seedlings irrigated with saline waters and cultivated in different types of environments and substrates. The experimental design was completely randomized with split-split plots, in which the plot corresponded to two growing environments $(\mathrm{EN} 1=$ full sun and $\mathrm{EN} 2=50 \%$ shade black net), the subplot to two types of irrigation water (IW1 $=0.8$ and IW2 $\left.=2.5 \mathrm{dS} \mathrm{m}^{-1}\right)$ and the sub-subplot to four types of substrates $(\mathrm{SB} 1=$ vermiculite + coconut fiber, SB2 = manure + soil, SB3 $=$ carbonized rice husk + soil, SB4 $=$ biochar + soil), with four replicates of twenty-five seeds. The variables analyzed were: emergence percentage (EP), emergence speed index (ESI), mean time of emergence (MTE), number of leaves (NL), stem diameter (SD), seedling height (SH) and root length (RL), shoot dry mass (SDM), root dry mass (RDM) and total dry mass (TDM). The EN2 treatment provided better conditions for emergence and initial growth, and EN1 was also favorable to the emergence and initial growth of watermelon seedlings, when the substrates SB1 and SB2 were used.
\end{abstract}

Keywords: Citrullus lanatus (Thunb.) Matsum \& Nakai. Protected environment. Salinity.

\section{ESTRESSE SALINO E AMBIÊNCIA NA PRODUÇÃO DE MUDAS DE MELANCIA}

RESUMO - Objetivou-se com este trabalho avaliar a produção de mudas de melancia irrigadas com águas salinas e cultivadas em diferentes tipos de ambientes e substratos. O delineamento experimental foi o inteiramente casualizado com parcelas subsubdivididas, sendo a parcela os dois ambientes de cultivo (AM1 = pleno sol e AM2 = telado preto com 50\% de sombreamento), a subparcela as duas águas de irrigação (AI1 = 0,8 e $\left.\mathrm{AI} 2=2,5 \mathrm{dS} \mathrm{m}^{-1}\right)$ e a subsubparcela os quatro tipos de substratos $(\mathrm{SB} 1=$ vermiculita + fibra de coco, $\mathrm{SB} 2$ $=$ esterco + solo, SB3 = casca de arroz carbonizado + solo, SB4 = biocarvão + solo), com quatro repetições de vinte e cinco sementes. As variáveis analisadas foram: porcentagem de emergência (PE), índice de velocidade de emergência (IVE), tempo médio de emergência (TME), número de folhas (NF), diâmetro do caule (DC), altura de plântula (AP) e comprimento da raiz (CR), massa seca da parte aérea (MSPA), massa seca da raiz (MSR) e massa seca total (MST). O tratamento AM2 propiciou melhores condições de emergência e crescimento inicial, já o tratamento AM1 também se mostrou favorável à emergência e crescimento inicial de mudas de melancia, quando utilizados os substratos SB1 e SB2.

Palavras-chaves: Citrullus lanatus (Thunb.) Matsum \& Nakai. Ambiente protegido. Salinidade.

\footnotetext{
${ }^{*}$ Corresponding author

${ }^{1}$ Received for publication in 01/13/2020; accepted in 03/20/2020.

${ }^{2}$ Department of Soil Sciences, Universidade Federal do Ceará, Fortaleza, CE, Brazil; juniorbarroso_99@hotmail.com - ORCID: 0000-0001 -9203-3886.

${ }^{3}$ Rural Development Institute, Universidade da Integração Internacional da Lusofonia Afro-Brasielira, Redenção, CE, Brazil; sousagg@unilab.edu.br - ORCID: 0000-0002-1466-6458, thssousa2015@gmail.com - ORCID: 0000-0001-9460-1461, ingrydnojosal@gmail.com - ORCID: 0000-0002-7793-9150, freddenilson@gmail.com - ORCID: 0000-0002-6365-6045.
} 


\section{INTRODUCTION}

The growing search for healthy foods has been attributing to the production of vegetable and fruit-bearing species more and more importance in the national and international scenario. One of these is watermelon [Citrullus lanatus (Thunb.) Matsum \& Nakai.], a species of annual cycle, native to Africa and belonging to the Cucurbitaceae family (OLIVEIRA et al., 2015a).

Watermelon is one of the main vegetables produced and consumed in Brazil, being cultivated virtually in almost all Brazilian states, but the technique for producing seedlings of this crop is on the rise in the scientific environment. For Magro, Salata and Cardoso (2011) the use of seedlings makes vegetable production more competitive and, consequently, more profitable. However, in order to produce quality seedlings it is necessary to provide the plant with adequate conditions for its development and, according to Natale et al. (2018), this technique constitutes one of the most important steps in the establishment and uniformity of orchards.

It is worth pointing out that in the seedling stage the type of substrate, protected environment, container volume, irrigation, fertilization and correct management of production operations provide conditions for obtaining plants with high quality, to ensure success in field development (COSTA et al., 2015).

However, the higher demand for water has led to the use of most of the water sources available in the Northeast region, forcing producers to use waters of different salinity levels at some point in the crop cycle, affecting germination and initial establishment of seedlings, due to the reduction in the water potential gradient between the seed and the soil/ substrate, besides inhibiting the mobilization of reserves and causing disorders in the embryonic axis membrane system (DUTRA et al. 2017).

Ribeiro et al. (2012) evaluated the effect of different levels of irrigation water salinity on the emergence and initial growth of 'Crimson Sweet' watermelon and found negative effects on both emergence and initial growth, but the reductions were lower during emergence. Costa et al. (2018) investigated the quality of yellow passion fruit seedlings in different combinations of substrates and environments and found that the use of environments and substrates exerts great influence in terms of seedling production, since they provide ideal conditions for production.

In this context, the objective of this study was to evaluate the production of watermelon seedlings irrigated with saline waters and cultivated in different types of environments and substrates.

\section{MATERIAL AND METHODS}

The experiment was conducted from October to November 2018 in the didactic vegetable garden of the International University of Afro-Brazilian Lusophony (UNILAB), Campus of Liberdade, belonging to the municipality of Redenção, Ceará, in the region of the Baturité Massif. According to Köppen (1923), the climate of the region is Aw', being characterized as tropical rainy, very hot, with predominant rains in the summer and autumn seasons.

A completely randomized experimental design was adopted in a split-split-plot scheme, in which the plot corresponded to two growing environments $(\mathrm{EN} 1=$ full sun and EN2 50\% shade black net), the subplot to two types of irrigation water $\left(\mathrm{IW} 1=0.8\right.$ and IW2 $\left.=2.5 \mathrm{dS} \mathrm{m}^{-1}\right)$ and the subsubplot to four types of substrates (SB1 = vermiculite + coconut fiber $-1: 1, \mathrm{SB} 2=$ manure + soil $-1: 1, \mathrm{SB} 3=$ carbonized rice husk + soil $-1: 1$, SB4 $=$ biochar + soil $-1: 1)$, with 4 replicates of 25 seeds. The soil used to prepare the substrates was Argissolo Vermelho Amarelo [Ultisol] (EMBRAPA, 2018). The chemical characteristics of the substrates used in the experiment can be observed in (Table 1).

Table 1. Chemical characteristics of the substrates used in the production of watermelon seedlings.

\begin{tabular}{|c|c|c|c|c|c|c|c|c|c|c|c|c|}
\hline & \multicolumn{12}{|c|}{ Chemical characteristics } \\
\hline & $\mathrm{OM}$ & $\mathrm{N}$ & $\mathrm{Ca}^{2+}$ & $\mathrm{K}^{+}$ & $\mathrm{Mg}^{2+}$ & $\mathrm{Na}^{+}$ & $\mathrm{H}^{+}+\mathrm{Al}^{3+}$ & $\mathrm{Al}$ & SB & $\mathrm{P}$ & CEC & $\mathrm{V}$ \\
\hline \multicolumn{4}{|c|}{$\left(\mathrm{g} \mathrm{kg}^{-1}\right)$} & \multicolumn{6}{|c|}{$\left(\mathrm{cmol}_{\mathrm{c}} \mathrm{kg}^{-1}\right)$} & $\left(\mathrm{mg} \mathrm{kg}^{-1}\right.$ & & $(\%)$ \\
\hline SB1 & --- & 0.60 & 13 & 73.51 & 378.33 & --- & --- & --- & 464.84 & 300 & 464.84 & 100 \\
\hline SB2 & 14.74 & 0.93 & 4.90 & 0.58 & 0.90 & 0.26 & 0.33 & 0.00 & 6.64 & 20 & 6.97 & 95 \\
\hline SB3 & 5.18 & 0.31 & 0.70 & 0.24 & 0.50 & 0.08 & 0.50 & 0.05 & 1.52 & 20 & 2.02 & 75 \\
\hline SB4 & 4.07 & 0.24 & 0.60 & 0.16 & 0.40 & 0.10 & 0.17 & 0.00 & 1.26 & 10 & 1.43 & 88 \\
\hline
\end{tabular}

$\mathrm{OM}$ - Organic matter; SB - Sum of exchangeable bases $\left(\mathrm{Ca}^{2}+\mathrm{Mg}^{2+}+\mathrm{Na}^{+}+\mathrm{K}^{+}\right)$; $\mathrm{CEC}-$ Cation exchange capacity $\left[\mathrm{Ca}^{2+}+\mathrm{Mg}^{2+}+\mathrm{Na}^{+}+\mathrm{K}^{+}+\left(\mathrm{H}^{+}+\mathrm{Al}^{3+}\right)\right] ; \mathrm{V}-$ Base saturation $-\left(\mathrm{Ca}^{2+}+\mathrm{Mg}^{2+}+\mathrm{Na}^{+}+\mathrm{K}^{+} / \mathrm{CTC}\right) \mathrm{x} 100$. 
The meteorological data obtained along the experimental period are presented in (Table 2).
During the experimental period there was a precipitation of $2.4 \mathrm{~mm}$.

Table 2. Mean values of temperature and relative humidity of the environments (full sun and $50 \%$ shade black net), along the experiment.

\begin{tabular}{ccccc}
\hline & \multicolumn{2}{c}{ Temperature $\left({ }^{\circ} \mathrm{C}\right)$} & \multicolumn{2}{c}{ Umidade (\%) } \\
\cline { 2 - 5 } & Max. & Min. & Max. & Min. \\
\hline Full sun & 34.5 & 32.6 & 53 & 47 \\
$50 \%$ Shade black net & 35.5 & 33.8 & 50 & 46.5 \\
\hline
\end{tabular}

The seedlings were produced using the cultivar 'Crimson Sweet', whose seeds were sown at $2 \mathrm{~cm}$ depth, in polystyrene trays with 200 cells of 40 $\mathrm{cm}^{3}$.

The amounts of the salts $\mathrm{NaCl}, \mathrm{CaCl}_{2} \cdot 2 \mathrm{H}_{2} \mathrm{O}$ and $\mathrm{MgCl}_{2} \cdot 6 \mathrm{H}_{2} \mathrm{O}$ used to prepare the irrigation waters were determined in order to obtain the desired electrical conductivity of water $(\mathrm{ECW})$ in the proportion of 7:2:1 (RHOADES; KANDIAH; MASHALI, 2000). Irrigation was manually performed at a daily interval, until the water drained from the bottom of the trays (MAROUELLI; BRAGA, 2016).

Until 14 days after sowing (DAS), the following parameters were evaluated: emergence percentage (EP), by correlating the number of normal seedlings emerged to the number of seeds sown; emergence speed index (ESI), determined by daily counts of emerged seedlings, adopting the methodology recommended by Maguire (1962); and the mean time of emergence (MTE), by daily counting the seeds, according to the methodology proposed by Labouriau (1983), with the results expressed in days, as well as mean speed of emergence (MSE) according to the methodology proposed by Carvalho and Carvalho (2009), with the results also expressed in days.

At 14 DAS, the seedlings were evaluated for: seedling height $(\mathrm{SH})$, measured with a graduated ruler, in centimeters, from the base to the apex; root length (RL), also measured with a graduated ruler, in centimeters; stem diameter (SD), measured at $1 \mathrm{~cm}$ height from the substrate with a digital caliper, in millimeters; and the number of leaves (NL), determined by counting the leaves that were fully open. After obtaining these data, the seedlings were placed in paper bags, identified and dried in an oven at $60{ }^{\circ} \mathrm{C}$ for 72 hours, until reaching a constant weight. These data were then used to determine shoot dry mass (SDM), root dry mass (RDM) and total dry mass $(\mathrm{TDM}=\mathrm{SDM}+\mathrm{RDM})$.

The results were subjected to analysis of variance and the means were compared by Tukey test with $\mathrm{p}<0.05$, using the program ASSISTAT 7.7 Beta.

\section{RESULTS AND DISCUSSION}

The analysis of variance showed significant interactions between the environment, irrigation water salinity and substrates for all variables: emergence percentage, emergence speed index, mean time of emergence and mean speed of emergence (Table 3).

Table 3. Summary of analysis of variance (ANOVA) for emergence percentage (EP), emergence speed index (ESI), mean time of emergence (MTE) and mean speed of emergence (MSE) of 'Crimson Sweet' watermelon seedlings as a function of different environments, substrates and levels of irrigation water salinity.

\begin{tabular}{cccccc}
\hline SV & \multicolumn{5}{c}{ Mean square } \\
\hline & DF & EP & ESI & MTE & MSE \\
\cline { 2 - 6 } Environment (EN) & 1 & $1,600.00000^{* *}$ & $8.76900^{* *}$ & $14.72641^{* *}$ & $0.00473^{* *}$ \\
Water (WA) & 1 & $256.00000^{\mathrm{ns}}$ & $1.79895^{* *}$ & $5.16426^{* *}$ & $0.00214^{* *}$ \\
Substrates (SB) & 3 & $772.00000^{* *}$ & $3.37862^{* *}$ & $6.45212^{* *}$ & $0.00231^{* *}$ \\
EN x WA & 1 & $196.00000^{\mathrm{ns}}$ & $0.33785^{\mathrm{ns}}$ & $1.05063^{*}$ & $0.00026^{\mathrm{ns}}$ \\
EN x SB & 3 & $1,004.00000^{\mathrm{ns}}$ & $3.89050^{* *}$ & $5.60009^{* *}$ & $0.00184^{* *}$ \\
WA x SB & 3 & $390.66667^{*}$ & $0.25123^{\mathrm{ns}}$ & $0.17570^{\mathrm{ns}}$ & $0.00003^{\mathrm{ns}}$ \\
\hline
\end{tabular}

**Significant by the $1 \% \mathrm{~F}$ test, ns: not significant. 
Table 3. Continuation.

\begin{tabular}{cccccc}
\hline SV & \multicolumn{5}{c}{ Mean square } \\
& DF & EP & ESI & MTE & MSE \\
\cline { 2 - 5 } EN x WA x SB & 3 & $525.33333^{* *}$ & $0.80403^{* *}$ & $0.87635^{* *}$ & $0.00021^{*}$ \\
Resíduo - EN & 6 & 69.33333 & 0.09168 & 0.19856 & 0.00008 \\
Resíduo - WA & 6 & 92.66667 & 0.09181 & 0.13324 & 0.00008 \\
Resíduo - SB & 36 & 96.55556 & 0.14148 & 0.16357 & 0.00007 \\
Total & 63 & & & & \\
Overall mean & & 89.5 & 3.50484 & 6.85313 & 0.14891 \\
CV - EN (\%) & & 9.3 & 8.64 & 6.5 & 5.88 \\
CV - WA (\%) & & 10.76 & 8.65 & 5.33 & 6.19 \\
CV - SB (\%) & & 10.98 & 10.73 & 5.9 & 5.43 \\
\hline
\end{tabular}

SV: Source of variation, DF: Degrees of freedom; CV (\%): Coefficient of variation, * Significant by the $5 \% \mathrm{~F}$ test, $*$ *Significant by the $1 \% \mathrm{~F}$ test, ns: not significant.

It can be observed in (Figure 1) that the environment under full sun negatively influenced emergence percentage (EP) in substrate SB4, differing statistically from the others, but with higher EP when irrigated using saline water with conductivity of $2.5 \mathrm{dS} \mathrm{m}^{-1}$. This result may be related to the acclimatization of watermelon seeds induced by osmotic adjustment when fertilized with this type of substrate and emerged under full sun.

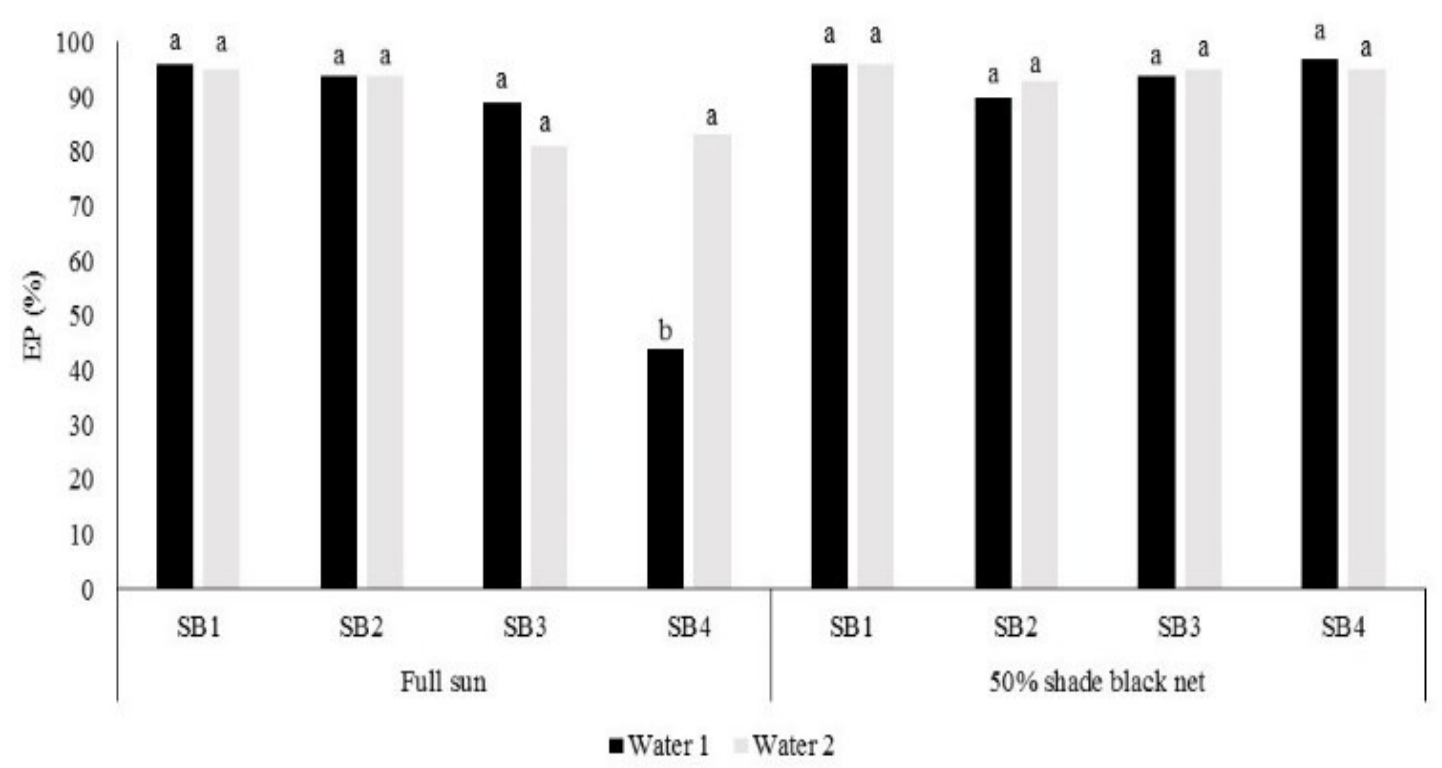

Figure 1. Emergence percentage $(\mathrm{EP})$ as a function of different substrates $(\mathrm{SB} 1=$ vermiculite + coconut fiber, $\mathrm{SB} 2=$ manure + soil, $\mathrm{SB} 3=$ carbonized rice husk + soil, $\mathrm{SB} 4=$ biochar + soil), salinities (IW $1=0.8 \mathrm{dS} \mathrm{m}^{-1}$; IW2 $=2.5 \mathrm{dS} \mathrm{m} \mathrm{m}^{-1}$ ) and environments.

Demontiêzo et al. (2016) observed similar results in tomato crop, in which the salt concentration of $2.5 \mathrm{dS} \mathrm{m}^{-1}$ promoted better EP. Contrary to this study, Ribeiro et al. (2012) evaluated the effect of different levels of irrigation water salinity on the emergence in watermelon seedlings and recorded a reduction in EP (\%) as the level of irrigation water salinity increased in the substrate from 0.17 to $5.5 \mathrm{dS} \mathrm{m}^{-1}$.

For the $50 \%$ shade black net (Figure 1), there was no significant effect between substrates and irrigation water for EP. This result may be related to 
the type of environment, that is, the black net can attenuate solar radiation during the day, providing better conditions for seeds to produce radicle and, therefore, better conditions for emergence (OLIVEIRA et al., 2015a).

For the emergence speed index (ESI), there was a statistical difference between the substrates SB3 and SB4 in the full sun environment when compared to SB1 and SB2. However, the SB4 under water salinity of $0.8 \mathrm{dS} \mathrm{m}^{-1}$ in the full sun environment led to the lowest mean value (1.22 seedlings day ${ }^{-1}$ ) (Figure 2). The stressful condition to which the seed was subjected may have induced the production of organic compounds and thus promoted its osmotic adjustment to such conditions, favoring its emergence when irrigated using saline water with conductivity of $2.5 \mathrm{dS} \mathrm{m}^{-1}$.

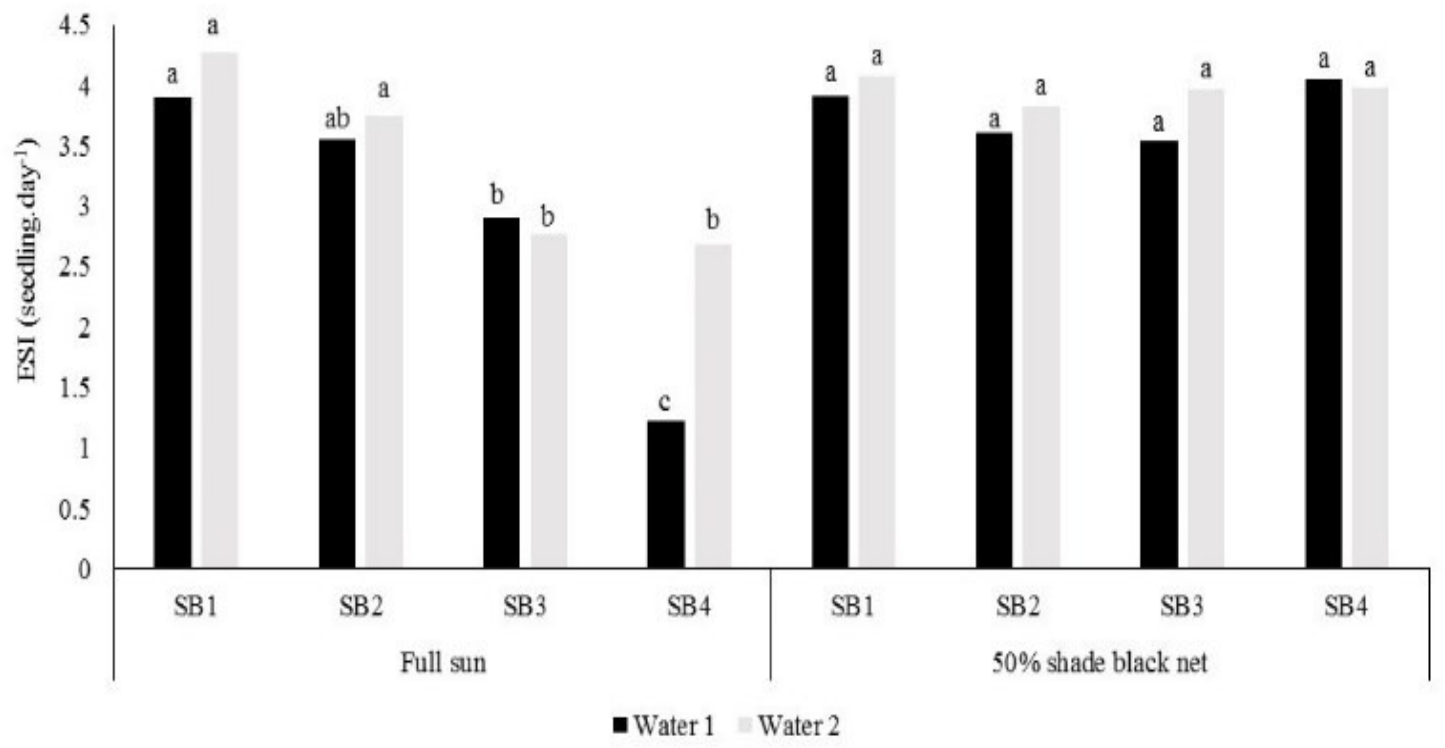

Figure 2. Emergence speed index (ESI) as a function of different substrates $(\mathrm{SB} 1=$ vermiculite + coconut fiber, $\mathrm{SB} 2=$ manure + soil, SB3 $=$ carbonized rice husk + soil, $\mathrm{SB} 4=$ biochar + soil), salinities $\left(\mathrm{IW} 1=0.8 \mathrm{dS} \mathrm{m}^{-1} ; \mathrm{IW} 2=2.5 \mathrm{dS} \mathrm{m}{ }^{-1}\right.$ ) and environments.

Contrary results were found by Ribeiro et al. (2012) when evaluating the emergence of mini watermelon, in which the increase in salt concentration directly influenced the osmotic potential of the substrate, hampering the availability of water, which influenced all variables related to the emergence process.

Figure 2 shows that there was no significant difference between substrates and irrigation waters in the presence of $50 \%$ shade black net. In contrast to these results, Costa et al. (2008) reported that, even in a greenhouse, ESI is inversely proportional to the increase in the levels of irrigation water salinity in the substrate.

Regarding the mean time of emergence (MTE), the environment under full sun influenced the substrates SB1, SB2 and SB3 (Figure 3). This result may be related to a possible compartmentalization of salts by seedlings that received saline water, so they were able to absorb water and accumulate toxic ions in the vacuole to prevent them from accumulating in the root zone (DIAS et al., 2016), that is, it probably led to higher emergence percentage, as well as a shorter mean time of emergence.

In the environment with $50 \%$ shade black net (Figure 3), there was no significant difference between the substrates and the irrigation waters. This may be related to the acclimatization of seedlings to the type of environment, contributing to increasing the tolerance of the seedlings to salt stress (LACERDA et al., 2016). Similar results were observed by Costa et al. (2009), who evaluated the effect of the environment on yellow passion fruit seedlings irrigated with low-salinity water. 


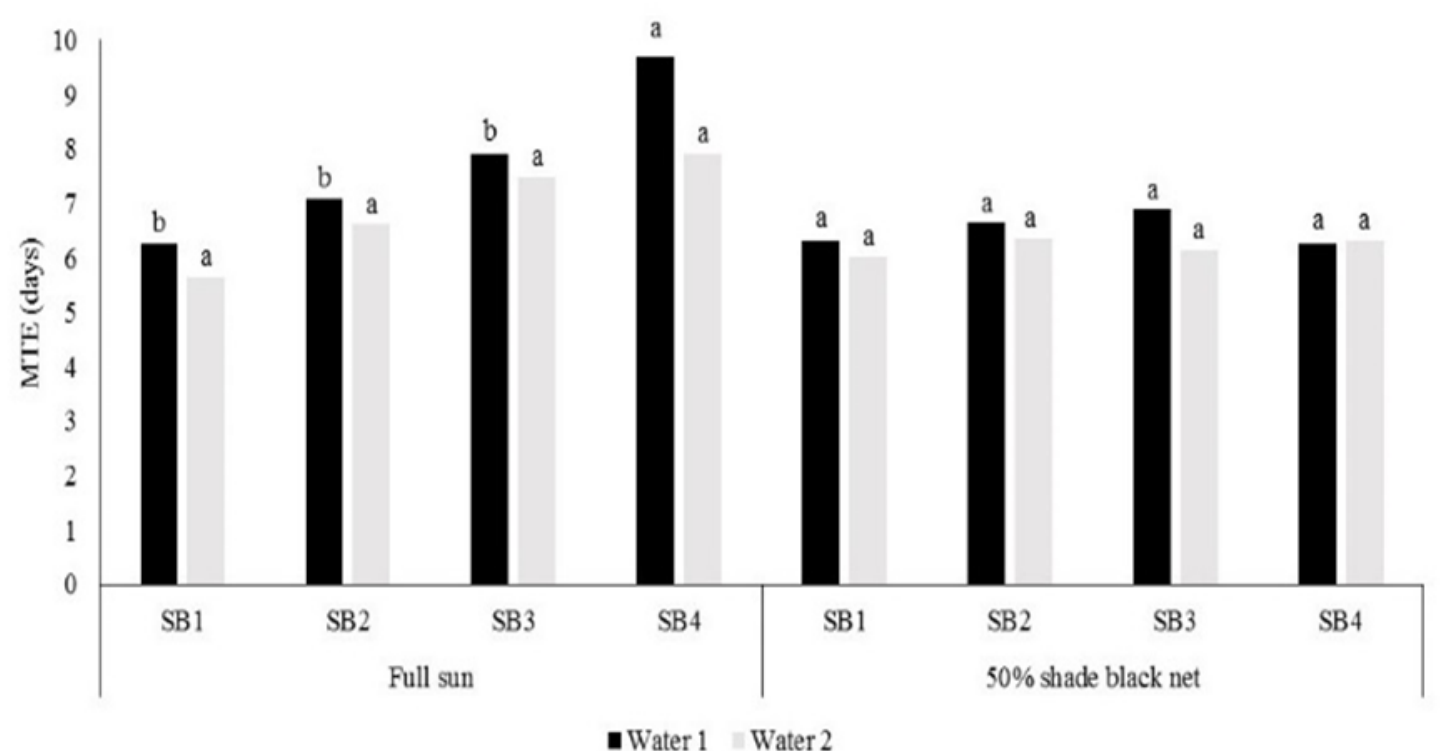

Figure 3. Mean time of emergence (MTE) as a function of different substrates $(\mathrm{SB} 1=$ vermiculite + coconut fiber, $\mathrm{SB} 2=$ manure + soil, SB3 $=$ carbonized rice husk + soil, $\mathrm{SB} 4=$ biochar + soil $)$, salinities $\left(\right.$ IW1 $=0.8 \mathrm{dS} \mathrm{m}^{-1} ;$ IW2 $=2.5 \mathrm{dS} \mathrm{m}{ }^{-1}$ ) and environments.

Regarding the mean speed of emergence (MSE), the lowest means were obtained in the substrates SB2, SB3 and SB4 in the environment under full sun (Figure 4). It is possible that these substrates in the environment under full sun did not provide favorable humidity and temperature conditions for seed emergence, since water absorption is fundamental for cotyledons to increase their volume, which leads to the breakage of the coat, facilitating the emergence of the root hypocotyl axis and other internal structures of the seed (BORGES et al., 2009).

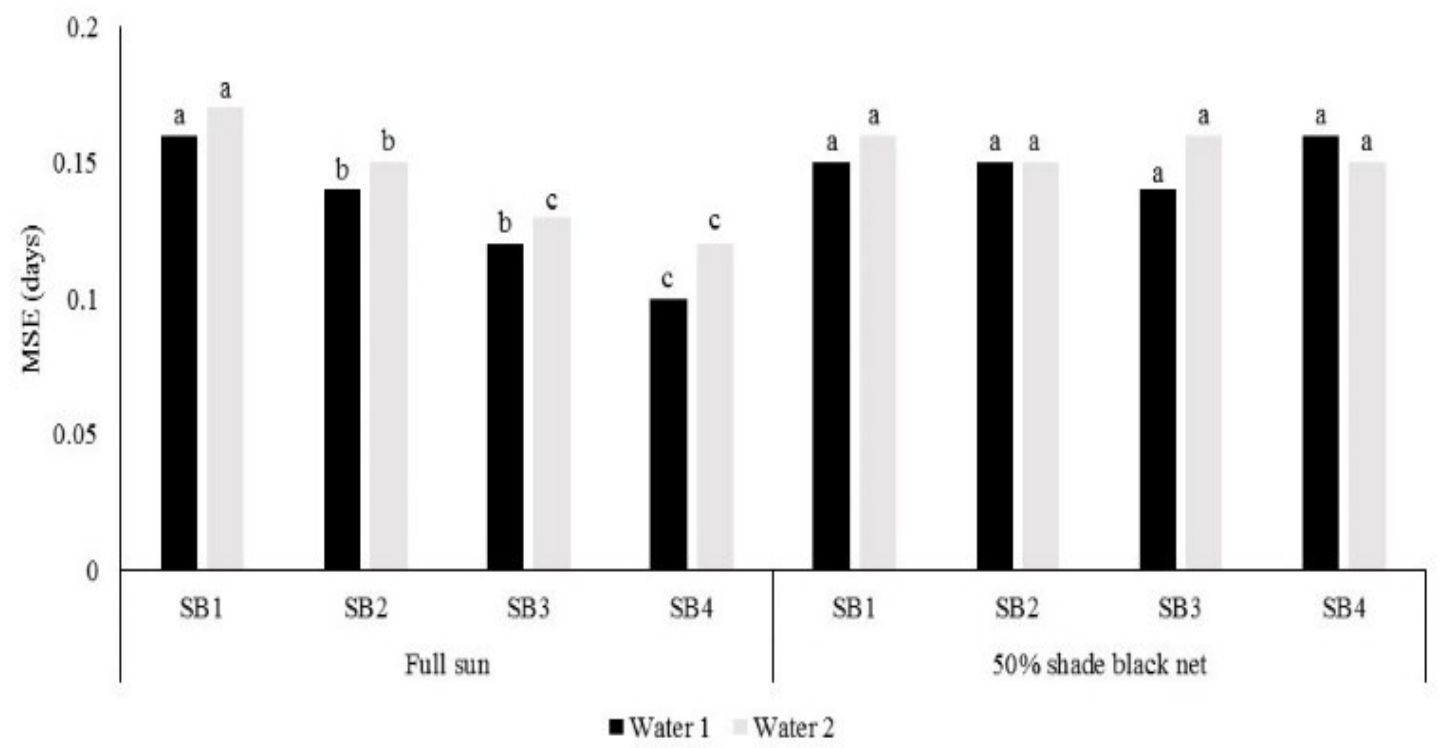

Figure 4. Mean speed of emergence (MSE) as a function of different substrates $(\mathrm{SB} 1=$ vermiculite + coconut fiber, $\mathrm{SB} 2=$ manure + soil, $\mathrm{SB} 3=$ carbonized rice husk + soil, $\mathrm{SB} 4=$ biochar + soil), salinities $\left(\mathrm{IW} 1=0.8 \mathrm{dS} \mathrm{m}^{-1} ; \mathrm{IW} 2=2.5 \mathrm{dS} \mathrm{m} \mathrm{m}^{-1}\right)$ and environments.

Corroborating these results, Oliveira et al. (2015a) investigated the production of watermelon seedlings and found better emergence indices with $50 \%$ shade net in substrate based on vermiculite + cassava stem + cattle manure. Oliveira et al. (2015b) found that salt stress increases the mean speed of emergence of beet crop when grown in a protected environment.

The analysis of variance shows that seedling height, root length and stem diameter responded to the single effects of the types of substrate, whereas shoot dry mass responded to the levels of irrigation 
water salinity. Seedling height was also significantly influenced by the interaction between the environment and water salinity. Similarly, shoot dry mass and number of leaves were affected by the interaction between environment and substrate (Table 4).

Table 4. Summary of analysis of variance (ANOVA) for seedling height (SH), root length (RL), stem diameter (SD), number of leaves (NL), shoot dry mass (SDM), root dry mass (RDM) and total dry mass (TDM) of 'Crimson Sweet' watermelon seedlings as a function of different environments, substrates and salinities of irrigation water.

\begin{tabular}{ccccccccc}
\hline SV & \multicolumn{7}{c}{ Mean square } \\
\hline & DF & SH & RL & SD & NL & SDM & RDM & TDM \\
\cline { 2 - 8 } Environment (EN) & 1 & $146.25^{* *}$ & $1.11^{\mathrm{ns}}$ & $0.14^{\mathrm{ns}}$ & $1.62^{\mathrm{ns}}$ & $319.73^{\mathrm{ns}}$ & $332.37^{\mathrm{ns}}$ & $1,304.11^{\mathrm{ns}}$ \\
Water (WA) & 1 & $6.84^{* *}$ & $0.03^{\mathrm{ns}}$ & $0.19^{\mathrm{ns}}$ & $0.05^{\mathrm{ns}}$ & $1,534.19^{*}$ & $33.27^{\mathrm{ns}}$ & $2,019.37^{\mathrm{ns}}$ \\
Substrates (SB) & 3 & $6.79^{* *}$ & $2.20^{*}$ & $0.43^{* *}$ & $0.26^{\mathrm{ns}}$ & $592.47^{* *}$ & $628.53^{\mathrm{ns}}$ & $377.38^{\mathrm{ns}}$ \\
EN x WA & 1 & $1.28^{* *}$ & $0.47^{\mathrm{ns}}$ & $0.54^{\mathrm{ns}}$ & $0.14^{\mathrm{ns}}$ & $16.15^{\mathrm{ns}}$ & $61.13^{\mathrm{ns}}$ & $140.12^{\mathrm{ns}}$ \\
EN x SB & 3 & $0.44^{\mathrm{ns}}$ & $0.23^{\mathrm{ns}}$ & $0.08^{\mathrm{ns}}$ & $0.36^{*}$ & $176.1^{*}$ & $159.01^{\mathrm{ns}}$ & $583.54^{\mathrm{ns}}$ \\
WA x SB & 3 & $0.18^{\mathrm{ns}}$ & $0.36^{\mathrm{ns}}$ & $0.06^{\mathrm{ns}}$ & $0.12^{\mathrm{ns}}$ & $27.8^{\mathrm{ns}}$ & $155.39^{\mathrm{ns}}$ & $54.96^{\mathrm{ns}}$ \\
EN x WA x SB & 3 & $0.41^{\mathrm{ns}}$ & $0.52^{\mathrm{ns}}$ & $0.11^{\mathrm{ns}}$ & $0.14^{\mathrm{ns}}$ & $123.99^{\mathrm{ns}}$ & $81.58^{\mathrm{ns}}$ & $385.99^{\mathrm{ns}}$ \\
Resíduo - EN & 6 & 0.65 & 4.69 & 0.09 & 0.36 & 113.99 & 330.15 & 574.29 \\
Resíduo - WA & 6 & 0.06 & 0.17 & 0.18 & 0.13 & 122.77 & 613.77 & $1,014.16$ \\
Resíduo - SB & 36 & 0.23 & 0.52 & 0.04 & 0.09 & 48.3 & 308.61 & 455.23 \\
Total & 63 & & & & & & & 23.77 \\
Overall mean & & 4.89 & 3.53 & 1.94 & 2.83 & 46.33 & 39.81 & 86.14 \\
CV - EN (\%) & & 16.47 & 61.39 & 15.9 & 21.38 & 23.04 & 45.64 & 27.82 \\
CV - WA (\%) & & 5.25 & 11.81 & 22.06 & 13.15 & 23.91 & 62.22 & 36.97 \\
CV - SB (\%) & & 9.87 & 20.48 & 10.73 & 10.80 & 15 & 44.12 & 24.77 \\
\hline
\end{tabular}

SV: Source of variation, DF: Degrees of freedom; CV (\%): Coefficient of variation, *Significant by the $5 \% \mathrm{~F}$ test, **Significant by the $1 \% \mathrm{~F}$ test, ns: not significant.

Regarding the interaction between environment and water for SH (Figure 5), seedlings grown under the $50 \%$ shade black net showed higher
SH compared to those under full sun when irrigated using saline water with conductivity of 0.8 and $2.5 \mathrm{dS} \mathrm{m}^{-1}$.

- Full sun $=50 \%$ shade black net

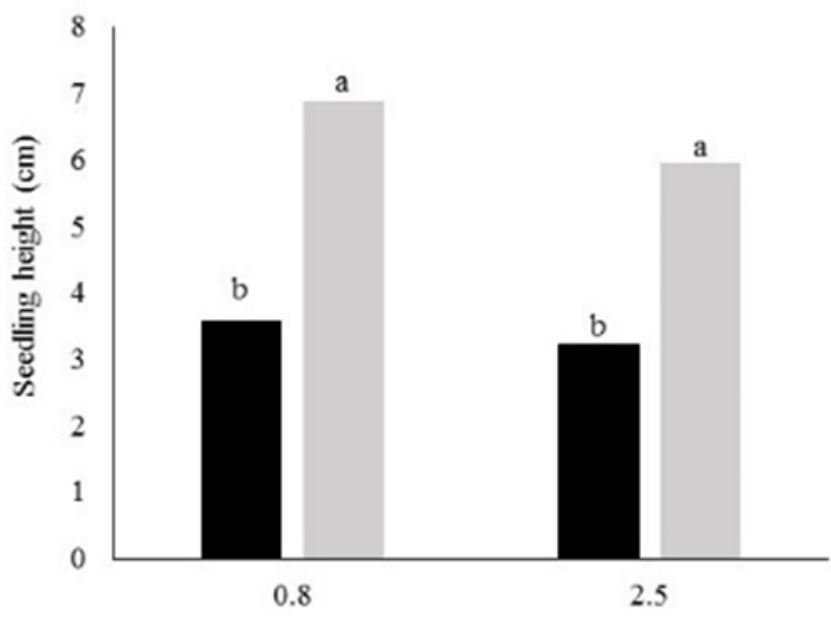

Electrical conductivity of water $\left(\mathrm{dS} \mathrm{m}^{-1}\right)$

Figure 5. Height of watermelon seedlings irrigated with saline waters grown in different environments. 
Similar results were obtained by Oliveira et al. (2015a), when evaluating the production of seedlings in a protected environment under irrigation with low-salinity water. For the effect of salinity, Ribeiro et al. (2012) also found an effect similar to that of the present study, in the production of mini watermelon seedlings irrigated with saline waters, in a full sun environment.

The mean values reveal that SB1 and SB2 were statistically superior to SB3 and SB4 for

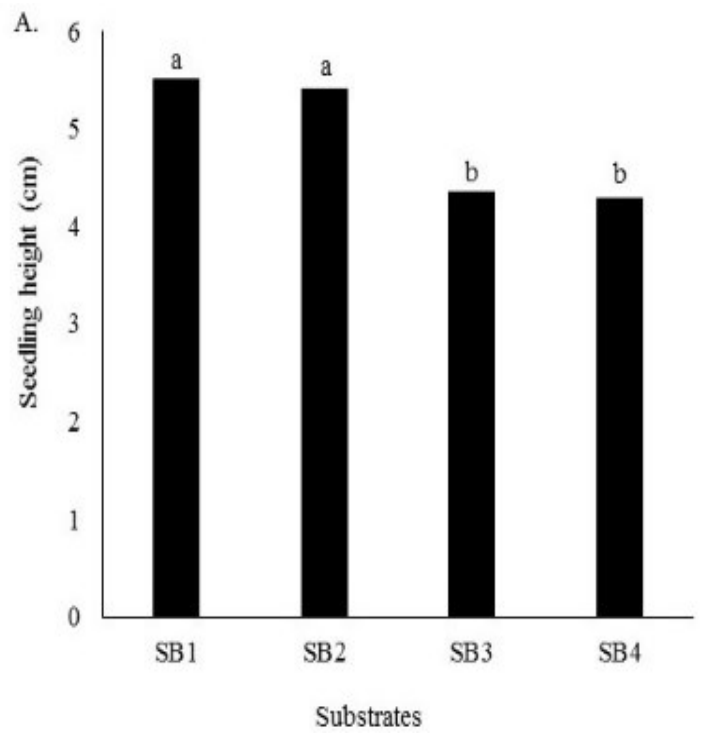

seedling height (Figure 6A) and stem diameter (Figure 6B), respectively. The positive effect of these substrates may be related to the characteristics of the material used for their production, which enabled a fast and efficient drainage, providing good oxygenation for the roots, large aeration space in the substrate, resistance to decomposition, relative structural stability, low density and $\mathrm{pH}$ close to neutrality (SOARES et al., 2012).

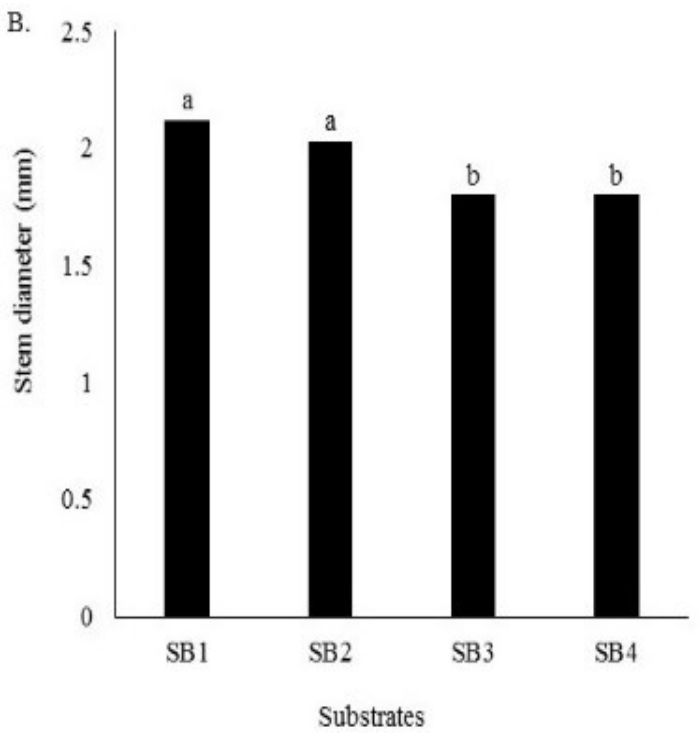

Figure 6. Height $(\mathrm{A})$ and stem diameter $(\mathrm{B})$ of watermelon seedlings as a function of different substrates $(\mathrm{SB} 1=$ vermiculite + coconut fiber, SB2 $=$ manure + soil, SB3 $=$ carbonized rice husk + soil, $\mathrm{SB} 4=$ biochar + soil $)$.

Similar results were observed in sweet yellow passion fruit seedlings by Lima et al. (2016), who found greater growth in height and diameter in substrates based on manure and/or vermiculite.

For root length (RL), it was verified that SB1, SB2, and SB3 did not differ statistically, but were numerically superior to SB4 (Figure 7). According to
Lima et al. (2013), this effect may result from the reduction of soil volume according to the volume of biochar, which decreases the amount of nutrients available, since biochar results from the pyrolysis of wood of different tree species and can act on the retention and not on the availability of nutrients.

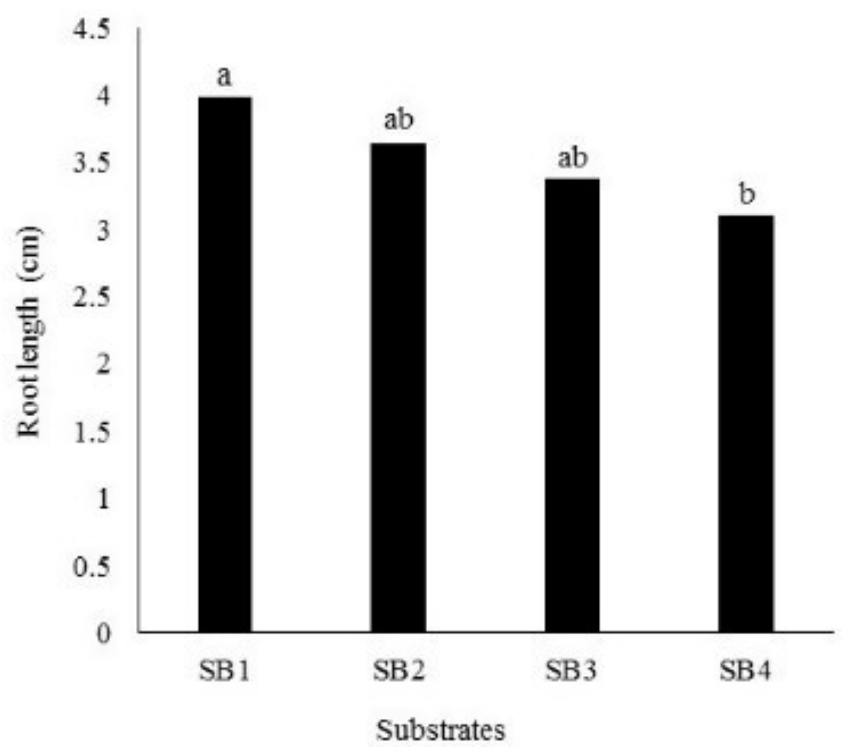

Figure 7. Root length of watermelon seedlings as a function of different substrates $(\mathrm{SB} 1=$ vermiculite + coconut fiber, SB2 $=$ manure + soil, $\mathrm{SB} 3=$ carbonized rice husk + soil, $\mathrm{SB} 4=$ biochar + soil). 
Corroborating this statement, Cavalcante et al. (2012) studied the formation of yellow passion fruit seedlings and reported that biochar promoted low root development when compared to other substrates.

Figure 8 shows that in SB3 and SB4 the number of leaves was statistically higher in the environment under $50 \%$ shade compared to that under full sun. Mezzalira et al. (2012) stated that this response may be related to the exposure of the plant to high temperature, which promotes higher photosynthetic activity. Similarly, Souza et al. (2011) found a lower number of leaves per plant under full sun conditions, in basil seedlings grown in a commercial substrate.

- Full sun $=50 \%$ shade black net

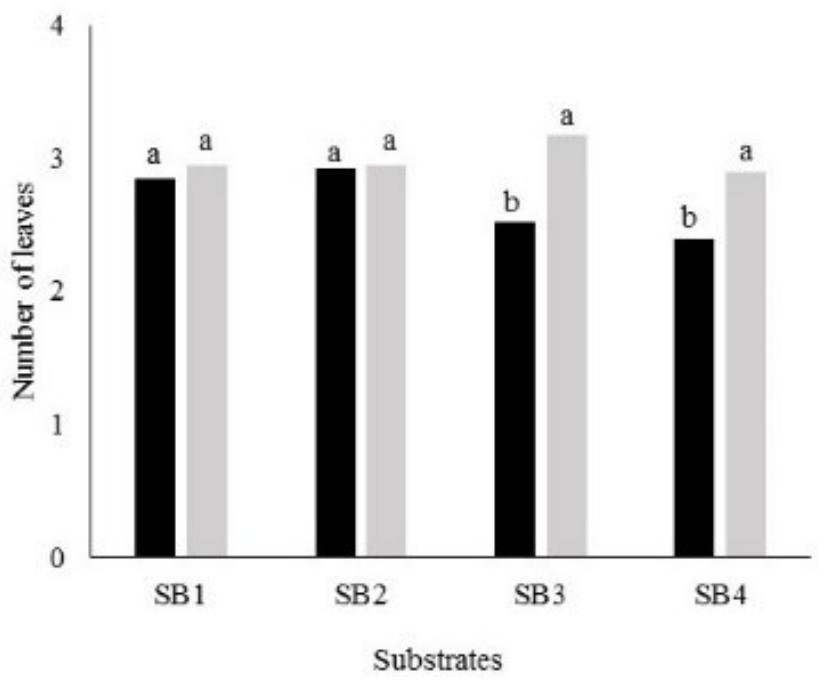

Figure 8. Number of leaves in watermelon seedlings as a function of different substrates $(\mathrm{SB} 1=$ vermiculite + coconut fiber, SB2 $=$ manure + soil, SB3 $=$ carbonized rice husk + soil, SB4 $=$ biochar + soil $)$ and environments.

The interaction between substrates and environments for shoot dry mass (SDM) is shown in (Figure 9A). The lowest means of SDM were obtained in the substrates SB3 and SB4, when present in the environment under full sun. Dry mass distribution among the different organs is a specific mechanism of plant species and demonstrates their adaptation to different environmental conditions (COSTA et al., 2018).
A.

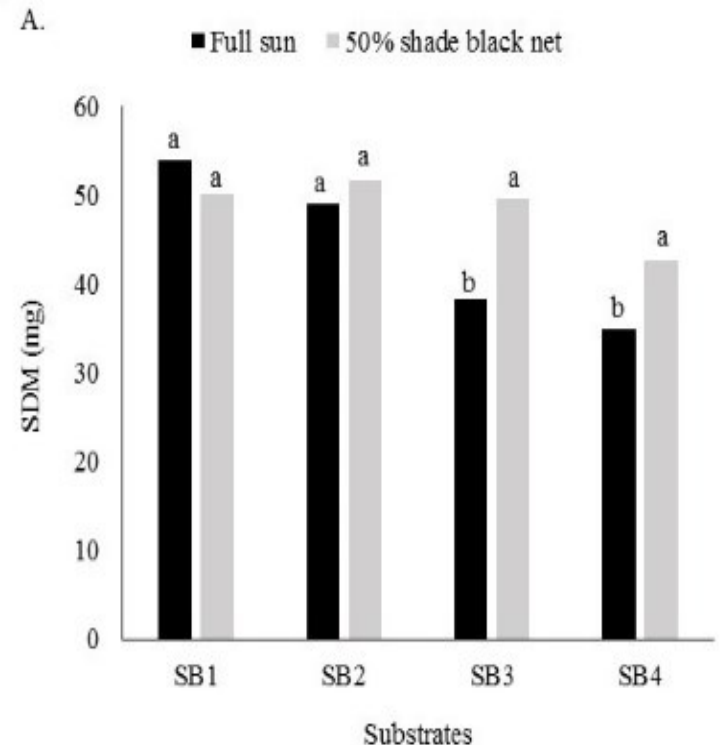

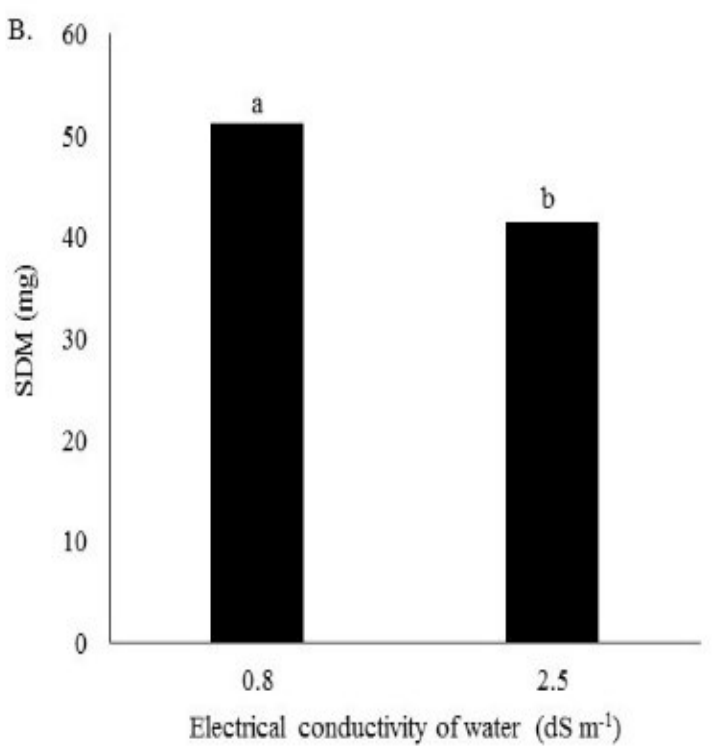

Figure 9. Shoot dry mass $(\mathrm{SDM})$ as a function of different substrates $(\mathrm{SB} 1=$ vermiculite + coconut fiber, $\mathrm{SB} 2=$ manure + soil, SB3 = carbonized rice husk + soil, SB4 = biochar + soil), environments (9A) and salinities (9B). 
These results contradict Oliveira et al. (2015a), who state that the watermelon cultivar 'Crimson Sweet' is more sensitive to shading, because it is prone to etiolation. Likewise, these results are also inconsistent with those obtained by Pereira et al. (2015), who investigated the effect of shading by different nets on yellow melon.

The results of the present study also demonstrate that seedlings irrigated with low-salinity water had higher SDM compared to those irrigated using saline water with conductivity of $2.5 \mathrm{dS} \mathrm{m}^{-1}$ (Figure 9B). The results of SDM are consistent with those found by Martins et al. (2013), who analyzed the initial development of watermelon cultivars under salt stress, and with those reported by Albuquerque et al. (2016), who studied the tolerance of cucumber cultivars to salt stress.

\section{CONCLUSIONS}

The environment under $50 \%$ shade black net provides better conditions for emergence and initial growth, regardless of the type of substrate or salinity of irrigation water.

The substrates Vermiculite + Coconut fiber and Manure + Soil, regardless of the salinity of irrigation water, were more efficient for the emergence and initial growth of watermelon seedlings when grown under full sun.

\section{REFERENCES}

ALBUQUERQUE, J. R. T. et al. Crescimento inicial e tolerância de cultivares de pepino sob estresse salino. Revista Brasileira de Agricultura IrrigadaRBAI, 10: 486-495, 2016.

BORGES, R. C. F. et al. Caracterização da curva de embebição de sementes de pinhão-manso. Revista Científica Eletrônica de Engenharia Florestal, 8: $1-8,2009$.

CARVALHO, D. B.; CARVALHO, R. I. N. Qualidade fisiológica de sementes de guanxuma em influência do envelhecimento acelerado e da luz. Acta Scientiarum. Agronomy, 31: 489-494, 2009.

CAVALCANTE, Í. H. L. et al. Biochar no substrato para produção de mudas de maracujazeiro amarelo. Revista de la Facultad de Agronomía, 111: 41-47, 2012.

COSTA, A. R. F. C. et al. Emergência de plântulas de melão em diferentes níveis de salinidade da água de irrigação. Revista Caatinga, 21: 89-93, 2008.

COSTA, E. et al. Telas de Sombreamento e
Substratos na Produção de Mudas de Dipteryx alata Vog. Floresta e Ambiente, 22: 416-425, 2015.

COSTA, E. et al. Efeitos da ambiência, recipientes e substratos no desenvolvimento de mudas de maracujazeiro-amarelo em Aquidauana-MS. Revista Brasileira de Fruticultura, 31: 236-244, 2009.

COSTA, F. M. et al. Produção de mudas de maracujazeiro amarelo em diferentes composições de substrato e ambiente. Revista de Ciências Agrárias, 41: 141-150, 2018.

DEMONTIÊZO, F. L. L. et al. Emergência e crescimento inicial de tomate 'Santa Clara'em função da salinidade e condições de preparo das sementes. Irriga, 1: 81-92, 2016.

DIAS, N. S. et al. Efeitos dos sais na planta e tolerância das culturas à salinidade. In: GHEYI, H. R. et al. (Eds.). Manejo da salinidade na agricultura: Estudos básicos e aplicados. Fortaleza, CE: Instituto Nacional de Ciência e Tecnologia em Salinidade, 2016, v. 2, cap.11, p. 151-162.

DUTRA, T. R. et al. Efeito da salinidade na germinação e crescimento inicial de plântulas de três espécies arbóreas florestais. Pesquisa Florestal Brasileira, 37: 323-330, 2017.

EMBRAPA. Sistema brasileiro de classificação de solos. 3. ed. Brasília, DF, 2018. 353 p.

KÖPPEN, W. P. Die klimate der erde: Grundriss der klimakunde. Berlin: Walter de Gruyter \& So., 1923. 369 p.

LABOURIAU, L. G. A germinação das sementes. Washington, D. C.: Secretaria Geral da OEA, 1983. $147 \mathrm{p}$.

LACERDA, C. F. et al. Estratégias de manejo para uso de água salina na agricultura. In: GHEYI, H. R. et al. (Eds.). Manejo da salinidade na agricultura: Estudos básicos e aplicados. Fortaleza, CE: Instituto Nacional de Ciência e Tecnologia em Salinidade, 2016, v. 2, cap. 21, p. 319-336.

LIMA, I. M. O. et al. Diferentes substratos e ambientes protegidos para o crescimento de mudas de maracujazeiro amarelo doce. Revista de Agricultura Neotropical, 3: 39-47, 2016.

LIMA, S. L. et al. Desenvolvimento de mudas de beterraba em substratos comerciais tratados com biochar. Agrotrópica, 25: 181-186, 2013.

MAGRO, F. O.; SALATA, A. C.; CARDOSO, A. I. I. Produção de repolho em função da idade das mudas. AgroAmbiente, 5: 119-123, 2011. 
MAGUIRE, J. D. Speed of germination-aid in selection and evaluation for seedling emergence and vigor. Crop Science, 1: 176-177, 1962.

MAROUELLI, W. A.; BRAGA, M. B. Irrigação na produção de mudas de hortaliças. Uberlândia, MG: Campo \& Negócios Hortifruti, 2016. 04 p.

MARTINS, D. C. et al. Desenvolvimento inicial de cultivares de melancia sob estresse salino. Agropecuária Científica no Semiárido, 9: 62-68, 2013.

MEZZALIRA, E. J. et al. Desenvolvimento inicial de plântulas de maracujazeiro azedo (Passiflora $\mathrm{sp}$ ) em resposta ao ambiente e ao tempo de armazenamento das sementes. Cultivando o Saber, 5: 113-123, 2012.

NATALE, W. et al. Evolução da nutrição mineral na formação de porta-enxertos e mudas de frutíferas. Revista Brasileira de Fruticultura, 40: 1-15, 2018.

OLIVEIRA, A. M. D. et al. Produção de mudas de melancia em diferentes ambientes e de frutos a campo. Ceres, 62: 87-92, $2015 \mathrm{a}$.

OLIVEIRA, F. A. et al. Emergência e crescimento inicial de plântulas de 276 repolho cv. Chato de Quintal sob estresse salino. Revista Agropecuária Técnica, 36: 273-279, $2015 \mathrm{~b}$.

PEREIRA, F. H. F. et al. Crescimento de planta, partição de assimilados e produção de frutos de melão amarelo sombreado por diferentes malhas. Ciência Rural, 45: 1774-1781, 2015.

RHOADES, J. D.; KANDIAH, A.; MASHALI, A. $M$. Uso de águas salinas para produção agrícola. Campina Grande, PB: UFPB, 2000. 117 p. (Estudos FAO - Irrigação e Drenagem, 48).

RIBEIRO, A. A. et al. Emergência e crescimento inicial da melancia sob estresse salino. Revista Brasileira de Engenharia de Biossistemas, 6: 3038, 2012.

SOARES, F. C. et al. Consumo de água pela cultura do lírio, cultivado em substratos alternativos em condições de ambiente protegido. Ciência Rural, 42: 1001-1006, 2012.

SOUZA, N. H. et al. Produção de mudas de manjericão (Ocimum basilicum L.) em diferentes substratos e luminosidades. Revista Brasileira de Planta Medicinais, 13: 276-281, 2011. 